\title{
THE PROBLEMS OF MAINTENANCE OF DRAINAGE DEVICES WITHIN MUNICIPAL AND DISTRICT ROADS
}

\author{
Zbigniew RESPONDEK \\ Czestochowa University of Technology
}

\begin{abstract}
:
The article presents technical aspects of maintenance of proper condition of drainage devices of public roads, and municipal and district roads in particular. The importance of road drainage is discussed, basic surface drainage devices discussed together with their location within the road. With use of actual examples we indicated the typical errors made during repairs and overhauls of the road, that have the consequence of disrupted continuity of drainage or the risk of quick loss of functions of drainage devices. The results of survey of technical condition of roadsides and the drainage device within a selected rural municipality were presented, indicating main problems of road keepers connected with keeping the drainage infrastructure in appropriate condition. The need of growing awareness in planning and designing road investment was indicated in the field of consequences of performing insufficient drainage.
\end{abstract}

Key words: road drainage, maintenance of public roads, drainage devices

\section{INTRODUCTION}

Municipal and district roads, when their total length is considered, have the biggest share in the road network [6]. They are located not just in rural areas, but also within city limits, forming the basic communication system for short journeys. Located both in built-up and undeveloped areas, they are rare find in dense urban areas. During the last twenty years the surface of those roads improved significantly - the repair of a road is usually an awaited effect connected with investments in infrastructure in the proximity of the road, most frequently new sewage installation and other pro-ecological investments completed within government programs, also with use of EU funding [10]. Sidewalks are also constructed in the road strip, improving its safety of use and aesthetics.

The average user focuses mainly on the condition of the pavement (its evenness, lack of dents and bumps), but the drainage devices are of no less importance - their construction, and most of all later proper maintenance may generate substantial spending for road keepers. Lack of care of drainage devices may lead to uncontrolled penetration of water to the core of the road and a deterioration of pavement that is much quicker than this assumed in the design [4].

\section{BASIC SURFACE DRAINING DEVICES}

Water is the factor behind the vast part of road pavement damages. It causes flushing down the pavement material, erosion of road embankments, splitting up of pavement after frosts and many other detrimental phenomena. Their consequences are dangerous enough for the durability of pavement structure, that the main task of road keepers should be the protection against the damaging influence of water. This task concentrates on not allowing the wa- ter running down from the pavement to reach the road core and to drain the flowing water from the pavement and lead it as fast as possible outside the road strip. Within the municipal and district roads the surface drainage devices are the most commonly used $[2,7,12,15]$.

The first element of proper road drainage is its proper pavement geometry. The ruling [9] recommends, for straight stretches of the road a two-sided elevation of $2 \%$ and in case of corners a single side elevation from inside to outside. The pavement shall not be flat longitudinally either.

If the surrounding land is characterized by good water permeability the road core can be shaped as a small embankment letting the water to be distributed to the surrounding area. This type of action is actually only possible in open areas.

Ditches are the most popular draining device. They are commonly used, although they are difficult to keep and troublesome when road safety is taken into account. Apart from roadside ditches also the draining ditches are important, that transmit the water to reservoirs outside the roadside. Culverts are connected with ditches, that is the pipes that are located underneath the surface of the road and its exits, that secure the continuity of water flow.

The water from the pavements can be drained directly to the ditches, with properly shaped, sloped roadsides or, e.g. in case of a road with a sidewalk, with gutters that ran along the side of the road. Simple gutters, formed on the connection of road pavement and curb are used, as well as those triangular and oval ones made of concrete blocks, and covered ones (e.g. box gutters). The gutter water is then led to ditches or outside in the field with use of connections located underneath the sidewalk or elements of 
the so-called underground drainage (inlets, inspection wells, drainage pipes, etc.).

Fig. 1 shows an exemplary location of drainage devices within a road.

\section{Errors commited during road repairs}

Road repairs should not only include the exchange of the pavement layers and the possible addition of sidewalk, but also facilitate road drainage. It is often that this latter element is not treated with proper care, resulting in errors being committed that end with lack of proper drainage [5]. Errors in this field include:

- wrong ditch geometry,

- lack of drainage continuity,

- deepening ditches below the culvert level,

- lack of drainage devices where they should be located,

- insufficient cross-section of inlets of water draining devices,

- lack of elements that facilitate passage on exits,
- wrongly executed roadsides

- insufficient embankment wall reinforcement, where it is required.

Regulations [8, 9] recommend trapezoid ditches for lower classes of roads, with wall inclination no greater than 1:1.5 and the ditch bottom not narrower than $40 \mathrm{~cm}$ and located no less than $20 \mathrm{~cm}$ below the drain outlet or the draining layer of the pavement. These omissions are, in many cases, the result of lack of space in the road strip (existing buildings).

When the pavement is repaired frequently also the so called "ditch cosmetics" are performed, that is the existing ditches deepened and profiled. Such actions, without placement or replacement of culverts do not lead to the bettering of drainage condition - just the opposite it negatively influences the condition of road core, as without continuity of drainage the water staying in the ditches undermines the road core. Such detrimental situations are illustrated in Fig. 2 .

Fig. 3 show examples of lack of drainage devices where they are needed.

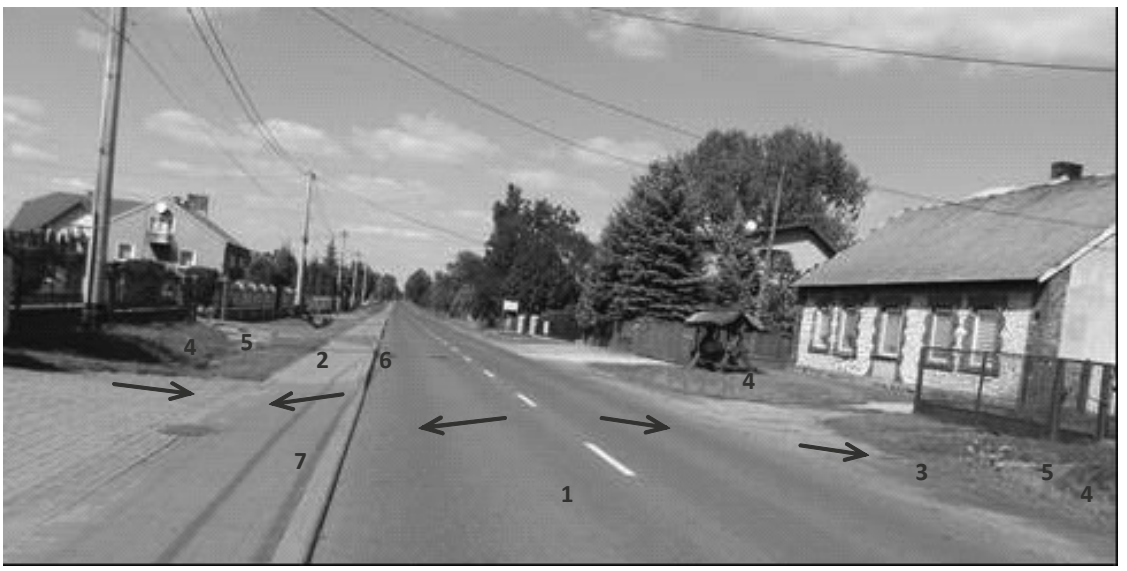

Fig. 1 Drainage devices of exemplary road in built-up area, the arrows show the perpendicular flow directions: 1 - road pavement with roof-like sloping, 2 - sidewalk, 3 - roadside (unpaved), 4 - road ditch, 5 - culvert under an exit, 6 - simple near-curb gutter, 7 - an exit with lowered curb

a)

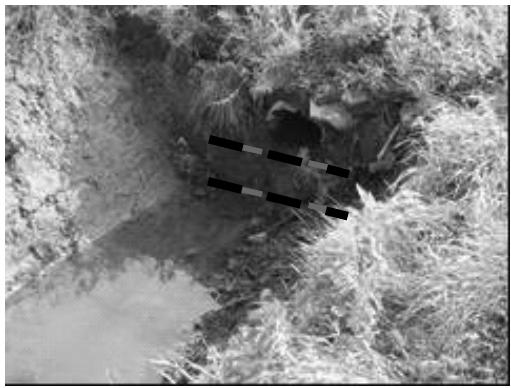

b)

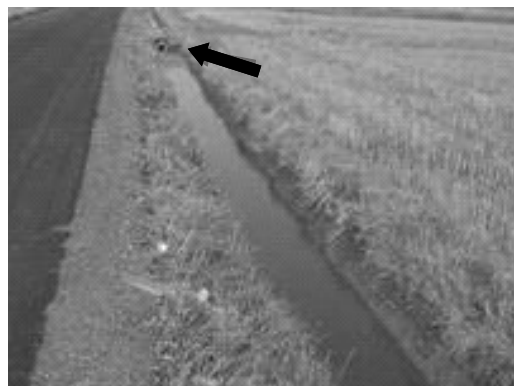

Fig. 2 Errors connected with ditch cosmetics:

a) ditch deepened below culvert level, b) results of lack or raising culverts - percipitation water stays in the ditch

a)

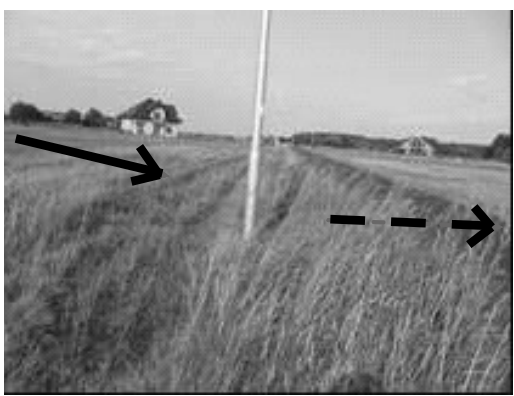

b)

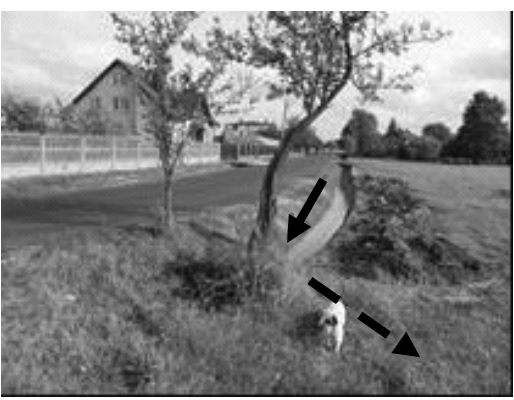


As we see on Fig. 3a the water from melting snow or heavy rainfall can't flow to the ditch located lower on the other side of the newly repaired municipal road - there is no profiled ditch nor a culvert. Another error is to construct a ditch, without a water reservoir connection (Fig. 3b).

And the inlet of the channel drain presented on Fig. 4 and designed to drain water from the gutter to the ditch has a too low cross-section, causing the water flow to be blocked.

Road repairs connected with construction of a sidewalk or sewage installation along the road, causes problems on house driveways. The drive through the sidewalk can be shaped in form of lowered curb (lack of evenness). In case of using triangular or oval gutters instead of curbs the road keeper should take into account, already at a design stage, devices that would facilitate driving over them, e.g. covering the gutter with metal sheets (Fig. 5a) or using a linear inroad with a comb-like profile [13]. Lack of such devices causes the inhabitants to "facilitate" the access with their own means, frequently doing that in a wrong manner (pouring concrete in the gutter, covering with gravel, placing wooden elements or steel pipes), that leads to blocking the flow of water and causing the silting of the gutter section above such an obstacle (Fig. $5 b, 5 c$ ). Fig. $5 d$ shows a case of placing a loose stone material roadside between the pavement and the gutter, with the gravel quickly filling the gutter.

If the roadsides are considered, the frequent shortcomings are:

- wrong sloping (Fig. 6a); the roadside should be sloping down from the pavement,

- using poor quality material, e.g. small particle gravel can get wet during rain and quickly tracked by wheels of the vehicles (Fig. 6b).

Fig. 7 shows an ex ample of deformation of sidewalk surface due to collapse of the neighboring wall that was inclined too steeply (even being reinforced with concrete openwork slabs) and undermined by the water flowing in the ditch.

\section{ANALYSIS OF CURRENT CONDITION OF DRAINAGE DEVI- CES ON THE EXAMPLE OF SELECTED MUNICIPALITY}

Table 1 presents results of own research of technical condition of surface and roadside drainage devices in the district roads of selected rural municipality of the Częstochowa district. The total length of evaluated stretches was $54.5 \mathrm{kms}$. The technical condition was evaluated pursuant to the grades recommended by the SOPO manual [11].

a)

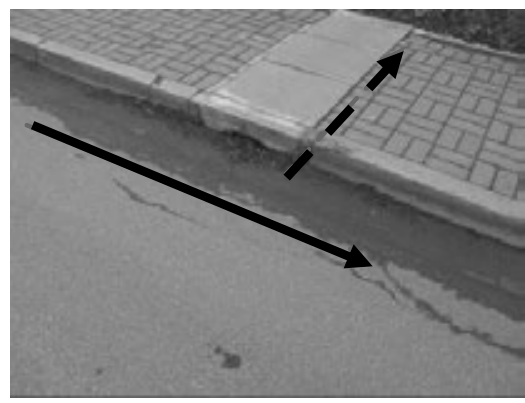

Fig. 4 Chanel drain of the curb gutter:

a) inlet blocked with rubble, b) lack of water run-off at the outlet

a)

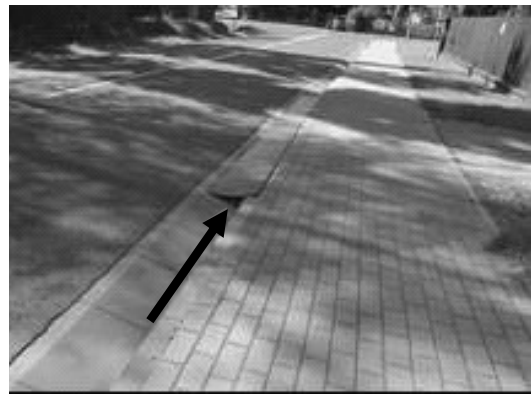

c)

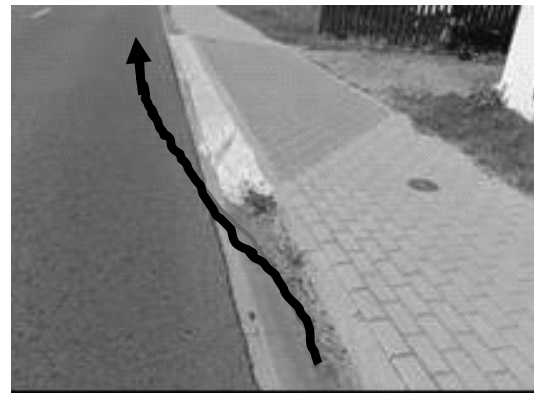

b)

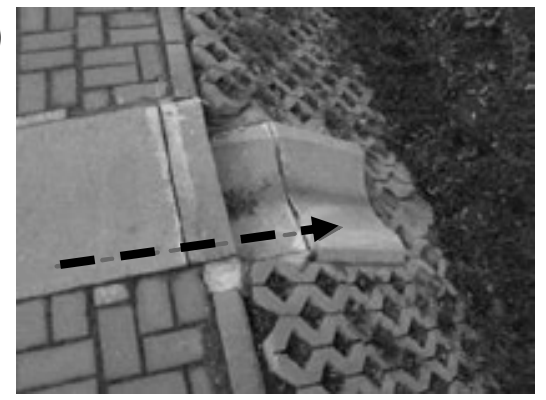

b)

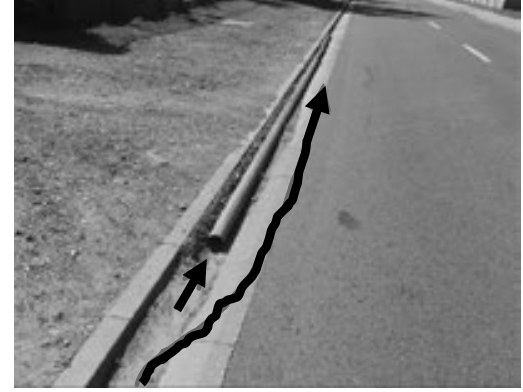

d)

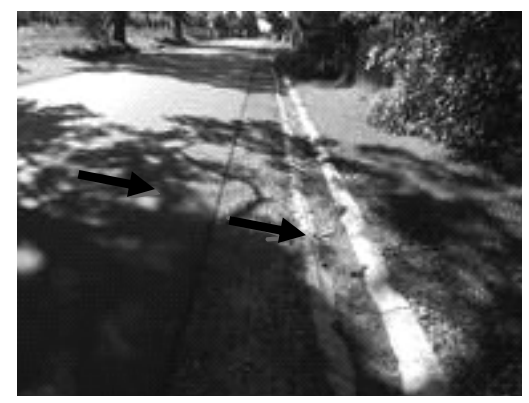

Fig. 5 Details of constructions connected with gutters:

a) covering a triangular gutter with metal sheet, drainage preseerved, b) use of steel pipe, drainage limited, c) pouring concrete - no drainage, d) filling an oval drain with material of wrongly placed roadside 
a)

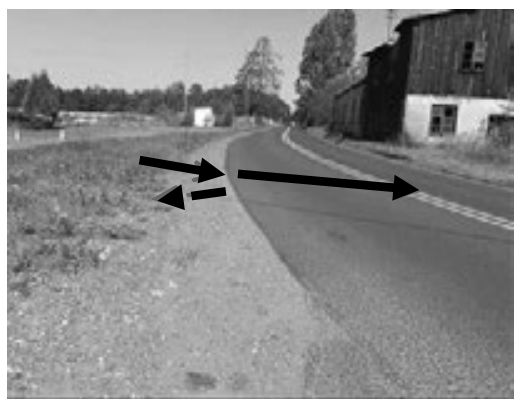

b)

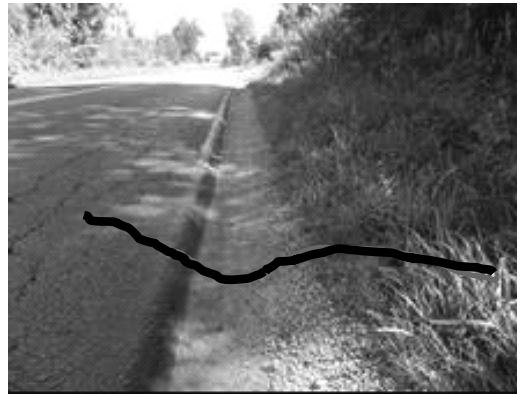

Fig. 6 Details of roadside construction:

a) a frequent case of roadside sloping down to pavement, b) tracked roadside that is too high at the same time

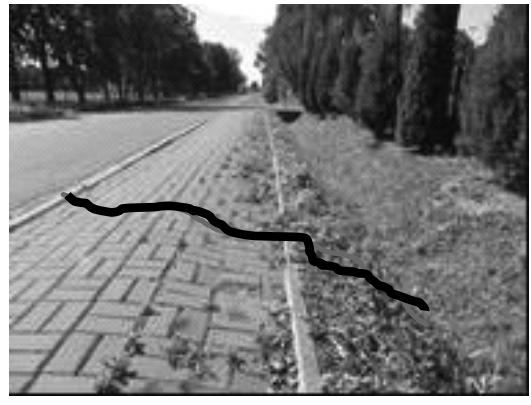

Fig. 7 Deformation of sidewalk due to collapse of ditch wall

Table 1

Evaluation of technical condition of surface and roadside drainage devices in the district roads of a selected rural municipality

\begin{tabular}{lll}
\hline Evaluation of condition & $\begin{array}{l}\text { Surface draining } \\
\text { devices (ditches } \\
\text { and culverts) }\end{array}$ & $\begin{array}{l}\text { Non-reinforced } \\
\text { roadsides }\end{array}$ \\
\cline { 2 - 3 } \% of total length of stretches \\
Good condition & 16.2 & 23.7 \\
Satisfactory condition & 20.6 & 9.7 \\
$\begin{array}{l}\text { Unsatisfactory condition } \\
\text { Bad condition }\end{array}$ & 17.2 & 7.4 \\
$\begin{array}{l}\text { Lack of surface draining } \\
\text { devices }\end{array}$ & 22.9 & 40.6 \\
$\begin{array}{l}\text { Lack of non-reinforced } \\
\text { roadside (sidewalk pre- } \\
\text { sent) }\end{array}$ & - & - \\
\hline
\end{tabular}

The presented results indicate the largely bad technical condition of drainage within the roads and reflect the scale of problems connected with maintaining the drainage device, that left to themselves lose their functions quickly. The phenomena lowering the functionality of drainage devices include:

- ditch walls overgrowing with plants or eroding,

- silting of ditches, culverts and gutters with parts of soil and organic matter,

- plants overgrowing the roadsides - this can also limit the visibility,

- the so called "swelling" of roadsides (raising above the pavement level) caused by soil undermining during frost or soil deposited by the flowing water.

The phenomena described above share one in common - they occur quickly, in weeks or months - necessitating maintenance procedures to be performed: mowing, cleaning silted devices, profiling of ditch walls and roadsides. In built-up areas the mowing of ditch walls and cleaning the culverts remains the duty of owners of the neighboring properties - these procedures are either performed or not, depending on the awareness and engagement of local population. The remaining tasks, including the keeping of outlet and irrigation ditches are the duty of local authorities, which having limited resources at their disposal, frequently perform these not frequently enough, or locally and in limited scope only $[1,14]$.

\section{SUMMARY}

Keeping the drainage devices in proper technical condition requires frequent maintenance and large expenditures, which is frequently a barrier for the keepers of municipal and district roads. Frequently the repairs and overhauls of roads are connected with construction of drainage devices and their increasing number generates problems with their maintenance. The results of research presented in this article indicate the largely bad or unsatisfactory condition of drainage devices, proving that the road keepers frequently have to choose between building or repairing pavements and proper maintenance of the existing ones.

The errors committed during road repairs presented in the article, most of all the discontinuity or obstruction of drainage result in eroding the road pavements, limiting the durability of road core and faster contamination of drainage devices - the can also negatively influence the possibility of flash flooding and floods and the safety of road traffic and travelling comfort. These errors should be eliminated on the design stage of investment and blueprints. It should be remembered that lack of patency of just a single culvert results in water accumulation and contamination of all drainage elements located above it.

There is need to increase the awareness and social responsibility [3] of both the road keepers, local authorities, residents and road investment designers and builders, pertaining to the need of keeping not just the pavement but also the elements of surface draining and roadsides in sound technical condition.

\section{REFERENCES}

[1] J. Bykowski and C. Przybyła, Kanały i rowy melioracyjne - aktualne problemy utrzymania [Online]. Available: http://www.inzynierbudownictwa.pl/ techni-

ka,materialy_i_technologie,artykul,kanaly_i_rowy_me lioracyjne_-_aktualne_problemy_utrzymania_,5738

[2] R. Edel, Odwodnienie dróg, Warszawa: WKŁ, 2000. 
[3] E. Gaweł, A. Jałoszyńska, M. Orłowski, E. Ratajczak, J. Ratajczak and B. Lara Riera, „Corporate social responsibility as an instrument of sustainable development of production enterprises", Management Systems in Production Engineering, vol. 3, no. 19, 2015, pp. 152155.

[4] K. Gudelis-Taraszkiewicz, „Odwodnienia dróg - bagatelizowany problem?", Magazyn Autostrady, no. 11, 2009, pp. 32-33.

[5] K. Gudelis-Taraszkiewicz, „Złe odwodnienia. Jak unikać zagrożeń?", Magazyn Autostrady, no. 10, 2008, pp. 126-127.

[6] Ministerstwo Infrastruktury i Budownictwa, Rodzaje dróg w Polsce [Online]. Available: http://mib.gov.pl/2RodzajedrogwPolsce.htm

[7] W.S. Młodożeniec, Budowa dróg podstawy projektowania, Warszawa: Wydawnictwo WAT, 2011.

[8] PN-S-02204:1997 Drogi samochodowe. Odwodnienie dróg, 1997.

[9] Rozporzqdzenie Ministra Transportu i Gospodarki Morskiej z dnia 2 marca 1999 r. w sprawie warunków technicznych, jakim powinny odpowiadać drogi publiczne $i$ ich usytuowanie, Dz. U. z 1999 r. nr 43, poz. 430, z późn. zm.

[10] M. Sikora, M. Kwiatkowski, K. Rudolf, K. Lorenc, H. Prosół and G. Heloise, „Financing pro-ecological investments by public funds in the lubuskie province in the years 2009-2013", Management Systems in Production Engineering, vol. 3, no. 19, 2015, pp. 156-160.
[11] System oceny stanu poboczy $i$ odwodnienia dróg (SOPO). Wytyczne stosowania. Załącznik A, Katalog najczęściej występujqcych uszkodzeń poboczy nieutwardzonych oraz elementów systemu odwodnienia dróg, Warszawa: GDDKiA, 2008.

[12] Z. Szling and E. Paczśniak, Odwodnienia budowli komunikacyjnych, Wrocław: Oficyna Wydawnicza Politechniki Wrocławskiej, 2004.

[13] A. Wysokowski, Odwodnienie parkingów i miejsc obsługi podróżnych cz. I-Odwodnienie powierzchniowe [Online].

Available: http://www.inzynierbudownictwa.pl/ drukuj,4118

[14] E. Zakrzewska, Wydatki na utrzymanie dróg sq zbyt mate [Online]. Available: http:// www.budownictwo.abc.com.pl/czytaj/-/artykul/ wydatki-na-utrzymanie-drog-sa-zbyt-male

[15] Zalecenia projektowania, budowy i utrzymania odwodnienia dróg oraz przystanków komunikacyjnych, Warszawa: GDDKiA, 2008.

\section{dr inż. Zbigniew Respondek}

Czestochowa University of Technology

Faculty of Civil Engineering

Chair of Construction Organization and Technology

ul. Akademicka 3, 42-201 Częstochowa, Poland

e-mail: zrespondek@bud.pcz.czest.pl zresp@o2.pl
Artykuł w polskiej wersji językowej dostępny na stronie internetowej czasopisma.
The article in Polish language version available on the website of the journal 